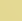



SB 933

.R43

Copy 1

\section{ON THE CONTROL}

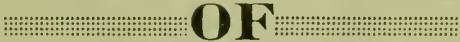

INSECTS

AND FUNGI.

COPYRIGHT, 1917,

By Fred Reinlein,

Portland, Oregon.

Circular No. 151.

JULY 20, 1917.

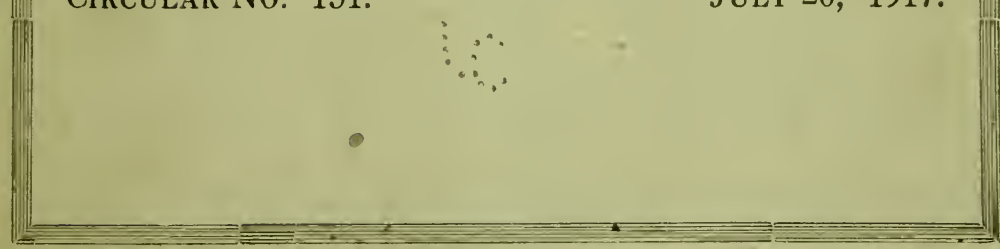




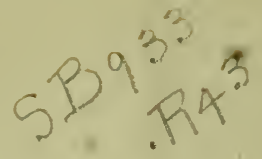

Several unfavorable conditions, largely $\ldots$ d by the war, combined to make it impracticable for me to read proof of this Circular. The result is, it contains considerable typographical errors. Taking the Circular as a whole I find that these errors do not lead to any misunderstanding. On page i 2, paragraph 3 , mention is made of an insect, admittedly extremely. injurious.' By this is meant the pear thrips. On page 32 you find 'The Cain Borer' for 'The Cane Borer,' also below, on same page, 'sweet and sour-sweet' for 'sweet and nonsweet.' On page 35 you find 'large pole pines' for 'lodge pole pine.' On page 36 'broadly impossible' for 'blandly impossible.' On page 37 'millions of feet' for 'billions of feet.' also 'preventative war' for 'preventive work.'

On page 39 'left us available places' for 'left no available places.' On page 34 it reads 'these savings' for 'these sowings.' Quotation marks have been left out in a number of places where they should have appeared.

\section{SEP 121917}




\section{ON CONTROL OF INSECTS AND FUNGI.}

Copyright 1917. By FRED REINLEIN,

Portland, Oregon.

Circular No. 151.

July 20, 1917 .

Inasmuch as anything new pertaining to agriculture cannot be satisfactorily introduced unless it can be shown that the matter had been submitted to the Department of Agriculture for examination, and had there been approved; it follows that it is the duty of the Bureau of Ethnology to define its position in regard to anything new that has bearing on the control of insects.

I have been wanting the Bureau of Ethnology to define its position on new matter for I9 years past. What the Bureau at present is wanted to act on is set forth in my Circulars No. I 48 to I50. There was no action of any kind whatever taken on my Circular No. 148, nor on those preceeding, as far back as No. I4 I. This was due, as explained in my Circular No. I50. to the failure of the Chairmen of the Congressional Committees on $\mathrm{Ag}$ riculture to do their duty.

With the appearance of my Circular No. I 49 Senator Geo. E. Chamberlain of Oregon was asked to see to it that the Bureau either admit that I am right, or else show wherein I am wrong. As explained on page 18 of my Circular No. I 50, Mr. Chamberlain was fair enough to give me a look at the two replies he received, which showed that the Bureau bad done neither of the two, but had handed him out a bundle of lies in each case.

Since Senator Chamberlain did not see to it that he got any desired information on any given point the matter was taken up with the congressman from the district I then lived in, Hon. W. C. Hawley, as stated on page I9, of my Circular No. I50. He too, got first of all, a bundle of lies.

Circular No. I 50 was meanwhile gotten out to explain in handy form just what the Bureau was most wanted to take action upon. Mr. Hawley was asked to see to it that action was taken, 
and here is the essence of the reply he got. "The suggestions made by Mr. Reinlein in this circular ( 150 ) have been examined by the experts of this Bureau, who are of the opinion that they are impractical."

It is all a lie. If the experts had investigated the suggestions they would not now want to hand out an opinion, for they would then positively say what their investigation had shown. An opinion, as used in law, is the formal decision of a judge or councelor; not a mere claim as is the statement of the Entomologist; but the claim is substantiated by giving the reasons upon which the claim is based. Members of Congress can be expected to know this.

For an illustration of how the Entomologist's claim works out, take the description of the control of the range caterpillar, as given on pages I to 3 , of my Circular No. I50. The Bureau has virtually nothing in the way of control that is tangible. They expect to control the caterpillar by natural enemies-parasites and predatory insects, saying the value of the crop is too small to allow of the use of artificial means, in the sense this form is generally understood, which is true.

Having nothing better to offer than the development of parasites and predatory insects, and expecting this to solve the problem, or at least make this do to placate the population of the affected territory, is equal to claiming that it would be possible to control the codlingmoth or any other insect by this course alone. Man can merely assist in establishing natural enemies, which in tur $\ddot{n}$ are often decimated by enemies of their own. The means of control I suggested, first published in my Circular No. I46, issued Aug. Io, I9I5, was calling for the systematic use of poultry.

This suggestion was new; and the Entomologist, assisted by his experts, could, without an investigation, right then have handed out an opinion, showing why they arrived at that opinion. They did nothing of this kind.

It had been shown to them that poultry could be made to attack the insect the year around, and it was shown to them at

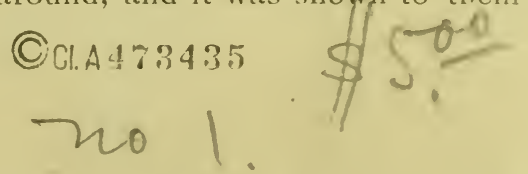


the very beginning that poultry is not expected at all to control the pest by attacking the full grown caterpillar, studded with hairs.

Investigations, in this case, could have been begun at anv day of the year, hence should have been started immediately.

Or, to put it another way for an illustration, the Entomologist wants to say, in this case, that his experts claim that poultry will not attack the egg clusters of the range caterpillar during the 8 months the caterpillar exists in this form. He wants to say that his experts claim, that as these egg clusters hatch and each egg develops into a little caterpillar a quarter of an inch long, poultry would not attack these young worms, that further, that these caterpillars while young, are gregarious and are nearly always exposed to view, poultry would not continue to eat these young worms in very large numbers. When present as pupæ this insect is greedily eaten by skunks, and the Entomologist wants to credit his experts with the claim that poultry would not eat these pupæ. Nor that they would eat of the moths, usually within easy reach.

As a field station was already established for the breeding of parasites, this investigation of the use of poultry could have been made in the easiest and most inexpensive manner.

As explained on pages 4 to io on my Circular No. I50, a judicious use of poultry can be made to absolutely control the bollwevil and the bollworm.

The Bureau's chief reliance for control of the bollwevil practically from the beginning has been the early burning of the stalks. As many farmers object to the burning, on the ground that it impoverishes the soil, the Buronu then conceeded that it might do to cut the plants up with the stalk chopper, plow the trash under immediately and harrow and drag the ground "to make it still more difficult for the insects to emerye," You see neither the burning nor the burying kills any appreciable number of the adults. The burning has the advantage in that it kills the immature stages in the infected squares and bolls; while the plowing in buries these immature stages and because of the looseness of the soil due to burying so much vegetable matter, 
many of these will mature and emerge before settled cold weather to successfully hibernate.

Again. these plants had been pumping water out of the soil very heavily for weeks, and the soil is apt to be very hard for anything like successful burying, and the work will be slow.

I had shown an improved way of securing the desired result, consisting in throwing the soil at the last two or three cultivations slightly towards the plant, sowing a cover crop, preferably a legume, vetches for instance, at the last cultivation, then cutting the plants off with the V stalk cutter when wanted, burning the plants, and then have thus at once the field produce pasturage, recovering from the air all and more of the carbonic acid and nitrogen that was lost through the burning of the plants.

Since neither burning nor burying of the plants kills any noticeable number of the adults the Bureau at an early date suggested that some of the plants be allowed to stand as traps, and the wevil were then there to be killed with crude oil. It is hard to see how such a scheme could work, since the adult can readiIy fly off and being chittinous all over, they should be able to stand a good bit of oil. Of late years nothing was heard of it, the idea having evidently been found to be absolutely impracticable and inefective.

Up to I9I 3 the bollwevil was not known to feed on anything other than cotton. Since then there was noted a decided tendancy of wevils to learn to feed and breed in plants other than cotton. As a consequence, as explained on page 8 of $\mathrm{my}$ Circular No. I50, I soon realized that by destroying the bulk of the plants and leaving a small part for traps, bending or rolling the plants down to bring the wevil within reach of poultry, the wevil would thus be exposed to attack till hibernation is fully under way, which in warm winters in the lower cotton belt does not occur at all, or is of very short duration.

This, as explained on page 9 of my Circular No. 150 , led to the suggestion of growing small patches of very late planted cotton purposely for traps, and in turn it was found that such trap patches would equally well serve to control absolutely the bollworm at the same time. 
With these trap patches in use a farmer may safely bury his plants if he prefers, since most adults resulting from buried squares and bolls would find their way to the trap patches to be picked off by poultry.

However, with a trap patch of late planted cotton on hand to attract and hold for poultry the wevils that will yet emerge from infested bolls and squares on the cut off plants, there is no need for the fertility destroying burning of the plants, nor for the cumbersome and doubtful burying. The burning of the stalks not only means a loss of organic matter contained in them but it means a much greater loss through the action of the fire on the soil. On the other hand the stalks, if left as they were cut off, will rot enough by becoming overgrown by the covercrop to cause no trouble when the covercrop is plowed in. The stalks thus act beneficially by lessening evaporation of water, by keeping a more even temperature, preventing eorsion, especially while the cover crop is yet small, and finally furnishing humus.

Poultry can, under the supervision of man, be forced to patrol the cotton fields during the growing season as needed. Early in the season cotton fields offer very little inducement for wild birds to visit them: food being found much more readily elsewhere, especially in woods and orchards.

If a field to be planted to cotton is properly plowed well ahead of planting time, few if any wevils that may have been hibernating within will he able to emerge, and infestation will be from without. As long as there are no squares, these wevils all stay close to the edge of the field, feeding in the tips of the plants where poultry can readily see them. By the time squares appear, usually only about half of the wevils have yet emerged. On pages 5 to 7 of my Circular No. I5o, you find explained in detail that wevils then promptly scatter over the field because they then want to feed and oviposit in squares, unless secured, by man under my former plan, and by poultry under my new plan, within a day or two after their arrival at the edge. Even then, however, infestation usually remains near the edge, gradually progressing all over the field as infestation increases. Thus it is doubtless best all around to leave the work of reducing the number of hibernated wevils to poultry. 
With the wevils reduced the fall before through the use of trap patches, and such trap patches again coming into use, in due time, the following season, and poultry on the watch virtually at all times, there is no chance for the wevil, the bollworm and most other insects to appear in harmful numbers; all of which the Entomologist claims he has investigated and found to be impracticable. This when he has nothing to offer for his plan of hand-picking by man, after the wevils have scattered all over the field, is only" "guardedly" recommended, so that he can make his get-a-way.

Cultivation destroys the natural home of wild birds. All the protection man can give under the circumstances is not sufficient to counterac't the decrease in numbers thus occasioned. Again, since cultivation destroys the fruits and seeds many of these wild birds normally live on, they cannot increase in numbers sufficient to at least partly protect the cultivated crops, without being compelled to levy a corresponding toll upon the crops. The gallinaceous domesticated birds are developed from a species that was capable of ready flight, lived io to I 5 years, the female laying a few small eggs each spring.

The domesticated kind, evolved by selection, being unable to fly to any extent, is thus specially fitted to work under the supervision of man when and where it is wanted, doing thus little or no harm, while doing good. And their number can be regulated by man entirely corresponding to the need for their services.

Thus, in the control of the three insects thus far mentioned, there does not enter the use of any artificial means, poultry, under the supervision of man, doing the work. Hence, this being a clear-cut issue, it would seem best to force the Entomologist to talk on these first.

I have shown in my Circulars Nos. I47 to 150 that there are many other insects where poultry can thus be used to best advantage; and quite a number where their use offers the only practical means of control. Grain and forage crops infested by pests, often can be similarly controled by poultry as is the range caterpillar, also it was shown that various caterpillars affecting 
timber trees can be controled by poultry when all else is impracticable, usually by the poultry scratching for their pupæ below the surface of the ground.

It is not often that an insect is exposed to view during all of its life cycle as is the range caterpillar, nor that it is within the easiest possible reach of poultry at all times.

The gipsy and browntail moth, considered as pests affecting woodlands, because of the loss value of trees grown for timber, call for inexpensive means of control. Farmers' Bulletin No. 564 issued in I9I4, pretends to offer such means. As explained more in detail on pages I 7 and 18 of my Circular No. 147, and on pages 7 and 8 of Circular No, I 49, poultry can reduce the gipsy moth in woodlands through securing part of the eggs, securing some of the young caterpillars that tall off the trees or spin down, scrape out older caterpillars that hide at the base of the trees during the day, and secure some of the females before they oviposit.

In addition, since the males are strongly attracted to light, they could be trapped with a trap such as I offer. This point is discussed on pages 4 to $T$ of my Circular No. 147. Also on pages I 4 and 15 of my Circular No. 149, in discussing the control of the leopard moth it is shown how the apparatus shown on last page, or some similar make, can be fitted at small cost for a trap to catch these insects in large numbers.

Farmers' Bulletin No. 788, the leopard moth, on page 9, gives a good idea of what Chief Howard thinks makes a trap. He says: "To what extent electric lights are serviceable ... has not been definitely determined, .... a method frequently advised consists in placing shallow pans around the electric light poles to attract the moths; the pans are partially filled with water and a small quantity of kerosene is poured into them. The moths flying against the globes drop into the pans and are promptly killed when they come in contact with the oil."

As these globes are suspended about twenty feet above the ground at the intersections of the centerlines of the streets, or driveways in parks, I cannot see how "pans placed around electric light poles" could ever be close enough to the globe to catch 
moth; and therefore, I contend that the advise is all drawn from imagination and that nothing whatever has been determined as claimed.

Also, Chief Howard does not want to talk about beneficial and neutral insects that would also be caught. When I sent my first catch-about I 500 insects. mostly ground beetles, which are, on the whole, beneficial - to the Bureau, Chief Howard said that if this is a fair sample of what the torch catches, its use should be prohibited by law.

To use any trap to advantage the user has to know at least approximately what kinds of insects he is catching, so that he may use the trap only when there is a paying catch of injurious insects being made. Assuming the Entomologist or someone else has a trap that works satisfactorily, it is the Entomologist's business to encourage its use and educate the public to usiug it. But with the Entomologist persistently claiming I am wrong all around, it is unwise for me to push the use of a torch for a trap and other matters, till other things not involving the use of any apparatus has been settled. On page 5 of my Circular No. I47, short reference is made to matter I published in regard to trap tests, made by the late Prof. M. V. Slingerland. Cornell University, Utica, N. Y. These tests showed that mere pans with water and kerosene do not catch anything worth while, and particularly nothing in the way of strong fliers, of which the leopard moth is one, and so is the male of the gipsy moth, and both sexes of the brown tail moth.

The method you find described by me admits the insects to the red hot burner through a ring of light about $\mathrm{I} 1 / 2$ inches wide. formed by two simple corresponding cone-shaped attachments placed at this distance apart, and because of the heat, the dazzling light - dazzling by comparison with the darkness outsideand the narrow space within, they become momentarily disabled and drop through a hole in the lower cone into a pail below. But where bright lights interfere, or if a wider range of attraction is wanted, as would he wanted in the case of timber insects in general, I would use something else.

The Bureau of Ethnology has no tangible means whatever 
for controling the gipsy moth in woodlands, except the breeding of parasites and predatory insects.

Since these parasites are admitedly equally subject to attack by natural enemies, they cannot, admitedly, be safisfactorly con. trolled by man.

The Bureau, because of this now proposes to give the advise to change as far as practicable the deciduous woodlands to coniferous ones, because the gipsy moth can live only upon coniferous after having passed the first two stages upon deciduous vegatation.

As explained on pages 2 to 5 of my Circular No. I48 and elsewhere, as there quoted, the pines of New England, and apparently all over the country, are now becoming infested by the European pine shoot moth. As this insect selects nearly always the apical bud for oviposition, if as yet uninfested, I had pointed out that pouring some semi-liquid clay into the apical cluster of buds before oviposition starts would protect it, the female then merely selectin a side shoot for oviposition.

The Bureau has no means of control. What they pass off as such is 140 years old and consists in removing the infected shoots. This, if the insect is at all plentiful, results in trees so crooked and dwarfed, dwarfed through the repeated destruction of the apical bud through successive rears, as to possess no value.

This insect is night flying, and as near as can be seen a satisfactory trap is the only feasible means of reducing the number of the adults.

There is no assurance whatever, in fact all odds are against it, that it would be possible to make it pay to so keep down deciduous vegetation that there would not be plenty of food to enable the gipsy moth to pass through the first two stages. But even if this were feasible, the Bureau has no means of controlling the pine shoot moth, and wants to condemn the plan evolved by me.

For control of the brown tail moth in woodlands the Bureau likewise, has nothing to offer, but claims that "elimination of 
oak, scrub-apple and wild cherry would greatly assist in reducing the numbers of this pest." (Farm Bull. No. 564, page 20). Oak is pretty hard to eliminate, and as the female can readily fly long distances, they simply would oviposit in orchards. Besides the caterpillar also develops very readily on plum and willow, also, for second choice, on elm and maple. In fact the caterpillar feeds generally upon all deciduous trees, on many shrubs and even upon herbage. (Farm Bulletin No. 264, page i6.)

It must be born in mind that for successful breeding little of the preferred food plants, such as oak, is needed to enable all the caterpillars hatching from eggs concentrated thereon to com plete about one-third of their growth, after which time they can, by migrating, complete their growth on less suitable food.

As both sexes are stronis flyers and much attached to bright lights, and because the females oviposit much more heavily in territory adjacent to bright lights. the most teasible means of protecting all of the valuable food plants thus affected would consist in trapping the adults at these lights. I have very deffinite ideas of how this could be successfully done, but with the Entomologist allowed to misuse his office I want to do nothing.

In woodlands, since these caterpillars frequently spin down, also often fall off, or blow off by wind, poultry would keep them at least partly under control. It is not known to what extent poultry can eat these harry caterpillars, but there is very little doubt that they can stand considerable of the smaller size when taken along with other food. The trouble is, neither the Bureau of Biological Survey nor the Poultry Division of the Bureau of Animal Industry have any positive knowledge on this point to offer. If the Entomologist had wanted investigations to be made, and the point is he claims his experts made investiyations of all of my suggestions, he had his own staff to do this quite easily.

On page I 8 of my Circular No. I 50 I stated that the alfalfa wevil is known to be readily found (and then eaten) by poultry. The source of information for this statement is found in Agricultural Bulletin No. I07, page 57 , contributed by the Biological survey, I9I4. The rather detailed evidence there given pretty conclusively shows that it is only a matter of getting e- 
nough of poultry on the job to make Mr. WVevil scarce. Under date of Jan. 6, I9i7, Mr. W. L. McAtee of the Biological Survey writes, in essence, that when opportunity affords, the Bureau will be glad to make observations on the use of poultry in destroying boll wevils, although the work relating to domestic fowls pertains to the Bureau of Animal Industry. Youthus here see that, in common with every sane man, Mr. McAtee does not look at such use of poultry as impractical suggestions as the Entomologist claims his experts pronounce it to be. The adult alfalfa wevil is of about the same size as the boll wevil. As for the immature stages, poultry forced to stay in cotton fields will be mighty quick to pick on fallen squares and should be quick in learning to hunt for the one containing a juicy grub. The Bureau of Entomology had far the best means and biggest oppropriations to test this out.

Since apple, pear, plum and cherry are the tavorite food plants of the browntail moth, orchards are their favorite feeding ground. This problem of control is discussed more in detail along with that of the gipsy moth at the passages cited. The young caterpillars hatch after the middle of August and spend the winter in webs in the top branches of the trees. In the spring "if the infection is bad, the caterpillars are often numerous enough to devour the leaves as fast as the trees are able to develop them." (Farm Bul. No. 564, page 9.) Thus since poison then could not be used, the Bureau advocates a spraying of 6 to Io pounds arsenate of lead to Ioo gallons of water, applied by the middle of August to kill the young caterpillars soon after hatching, a course expensive and uncertain, because there is much vareation in time of hatching. and objectionable of danger of poisoning fruit.

Of course a high power sprayer is required, The young caterpillar, if not killed then, will do but little damage that fall, and an excellent way of control would be to go over the orchard after the most of the leaves have fallen, say after the middle of October, with a torch outfit constructed after the principle of the towersprayer outfit, as described on pages I I to I 3 of $\mathrm{my}$ Circular No. I47. Selecting a warm spell the caterpillars will be ac- 


\section{(12)}

uve and drop ott upon teeling the heat. This would not kill them, at least not at once, but poultry might be kept handy to pick them up. They are then only about one-half inch long. Besides in the absence of poultry, the ground can be licked where they fall, thus killing them.

This use of the torch makes for the cheapest insect killing agent known, where chemicals cannot readily be used. Also the flame destroys the spores of fungi. This was conceeded as far back as I 3 year ago by the State Entomologist of Illinois, a matter discussed at some length on pages $\mathrm{ro}$ and $\mathrm{I} 2$ of $\mathrm{my}$ Circular No. I48. Every one connected with agriculture in the Eastern States knows of the damage done by fungi. During hot moist weather in summer, a licking with a torch is extremely swift and cheap, and works in wet weather, while spraying does not.

A torch outfit of the tower type, it is shown on page 9 to I 3 of my Circular No. I 47 , is far the best means of controlling the insect, admitedly extremely injurious, now getting a good foothold in the East. As there explained all you have to do is apply a mild licking with the flame while the insect is in the larval stage, when upon feeling the heat they will drop, when they can be killed through more heat applied to the ground. The Bureau has nothing at all that can approach this in cheapness and efficiency.

As near as I ever could learn, I was the first to apply heat from a torch for the destruction of insects. I did this first in the late summer of 1896 , with a view of trying to get rid of harlequin cabbage bugs. The following year this was kept up on insects in general, and it was incidentally found, that the adult harlequin bugs would fly to tassels of sweet-corn, where they could be more easily secured. I suggested to the Secretary of Agriculture in I898. after publishing what I had found, that this and other original knowledge I had published be acquired for the public benefit. He said the government never had done anything of this kind. Bad as this was the Entomologist now goes him one better and claims I am wrong all around, Taking this harlequin bug for example, the country must sustain needless heavy loss. In my Circular No. I4I I had pointed out that hetter 
trap-plants for this insect could be secured by seeing to it to have always some coneiferous plant going to seed, as then the bugs would congregate on the seed stalks. Again, on page 24 of my Circular No. I 47 it was further shown that poultry given access to these trap plants would pick off the adults, and thus the whole maiter of disposing of these highly troublesome pests can be made to almost take care of itself. This insect is highly injurious in the Southern States. Thus the New Mexico Experiment Station in one of their latest reports states that this insect ranks first as a truck-crop pest in that state, 'The Entomologist has nothing that is practicable.

Another highly injurious sucking insect for the control of which the Entomologist and his boasted experts have no practical means of control is the Mexican Conchucla, referred to in various places in my Circulars No. I47 to 150 , and discussed in detail in my Circular No. I40, pages I to I5. This insect feeds on almost anything, but prefers fruits and seeds.

Poultry in quantity will keep them in check on alfalfa or other early lowgrowing crops, and by seeing to it that suitable trap-crops Milo-maize for instance, to concentrate them on, are supplied later, and have them picked off there by poultry, such crops as peaches or grapes can largely be kept free.

This application of heat is also far the best means of control for insects hiding in the ground or about a plant during the night and cool part of the day, of which class the hop flee beetle and the chinch bug are good examples, Ther are discussed at length in previous Circulars.

If the loss to Texas by the boll weevil is 27 million dollars a year, it is about 75 million for all of the infested area. My plan saves this whole loss since under it poultry will keep this and other pests in check, so that the plant will be able to set all the fruit it can possibly mature. Taking all the evidence submitted by me, it is worth in insect-and fungus control over half a billion dollars a year.

Representative Hawley upon getting his second batch of lies was asked to see to it that the Entomologist be forced to 
meet the issue. He did not secure any further reply. In common with all the other members of Congress I had tried before, with one exception, he did not want to express himself in any way as to whether or not the evidence submitted is sound, just as if he, in common with the rest, had no brains at all, and were not expected to have any and to use them.

The exception in the case is the representative of the 2nd California District, Hon. John E. Raker, to whom reference is made on page 12 of my Circular No. I48. Upon the issuance of my Circular No. 147 his attention was called to this matter, because Senator Gore had flatly refuse to do his duty, and he declared himself ready to see to it that it be carried through for whatever merit it might possess for the benefit of the public. In common with everybody else, including the Entomologist, he was unable to point out anything that was not sound reasoning.

When my Circular No. I 48 appeared in March I9I6, he suggested, since Senator Gore and Representative Lever had taken no action, that I take the matter up with Senator Morris Sheppard, he being chairman of the Committee on Expenditures in the Department of Agriculture. This was done and the matter was brought to the attention of many other members of Congress, which caused Mr. Raker to remark that this should bring results. The results wanted were, that the Entomologist be forced to either admit that I am right, or show wherein I am wrong. Well, it did not bring any such results. Upon the issuance of my Circular No. I 49 Senator Sheppard was again kept posted and he asked the Department of Agriculture for an explanation. The result was that under date of August i 5 he wrote me he had been advised my plans are not practicable, and that therefore he' did not desire to push the matter further. He never gave me a look at what advise he got. Thus, he wanted to hang me without a chance of defense.

Meanwhile Mr. Raker was kept posted, and upon getting a copy of my Circular No. I 50 , he wrote, "Keep up your work and results are bound to follow." This was not saying much, but was saying more than all the rest of the Congressmen I had tried 
before, put together. He, being unable to see anything but sound evidence, simply wanted me to see it through, believing this to be best for the public weal.

The evidence submitted shows that the Entomologist is humbugging the people with their own good money. That, therefore, there is not a Congressman whose constituants are not affected, and that, therefore, all members of Congress are in duty bound to have the matter sifted to the bottom.

Mr. Raker having expressed a willingness to co-operate with Mr. Hawley to the extent of getting the U.S. Entomologist to define his position, he was asked, while this Circular was being prepared, to use his influence to get the Entomologist to act. As a result I receive on March I 7 th a copy of the reply Mr. Raker had received from the Department of Agriculture. It simply was a bundle of lies However, unlike all previous statements it contained specific statements which were expected to be taken for proof by Mr. Raker that I am wrong. These statements, al! short, refer to the control of the range caterpillar, the boll wevil and the Argentine ant.

In the case of the range caterpillar the Department claims that my plan of control consists in "that turkeys be secured in sufficient numbers to destroy the insect. It has been shown however, that on account of the poisonous hairs born by the caterpillar. turkey's will not feed upon it." This when it had been pointed out to the Bureau from the beginning, nearly two years ago, that the period when the caterpillar has poisonous hairs is the most unfavorable time to attack it, that the insect is within the reach of poultry the whole year around, and that the correct time for attack is while it is present as egg, as young larva, as pupæ and as adult, as explained in detail' on pages $I$ to 4 of my Circular No. 150 , and also in this Circular.

As the adults deposit their eggs on stems of wild grasses or on weeds, the resulting caterpillars, no matter how plentiful, find enough food for partial development on the range, but as they run short, they attack, as far as accessible, cultivated grasses and grains. It would be quit impossible to protect these crops 
by poisoning, since the caterpillar, being of the class of the tussock moth, the gipsy moth and the browntail moth, or well known to be extremely resistant to poisons once they are alcut one-third grown, hence coming as they do in hordes, they would usually eat up the crop first before the poison could have any possible eftect. Hence with the Bureau silent on this point all along, the only possible means of protecting cultivated crops consists in keeping them down to harmless numbers on the range.

The Bureau's only proposed plan of control consists in relying on artificial introduction of parasites and of predatory beetles. This is also the course that has been followed for the control of the gipsy moth in woodlands. But the Bureau frankly admits that these parasites may in turn be decimated at any time by hyper-parasites preying upon them, and for this reason the Bureau pointed out that a surer means of avoiding damage consists in changing the easily injured deciduous woodlands to less easily injured coniferous tracts; a proposition that holds out no chance of financial success.

In regard to the possibility of growing grain for poultry in the range caterpillar belt. Mr. H. N. Vinall, of the Bureau of Plant Industry was sounded for an opinion. He said in substance that while rainfall is lisht even for sorghums it is possible to grow fair crops of Dwarf milo and feterita. For details see Farmers' Bulletin No. 322, and Circular No. I 22 C.

In regard to my plan for controlling the boll weevil the Department says: "Mr. Reinlein's suggestion is that chickens be provided in sufficient numbers to destroy all or most of the weevils as soon as they make their way into the fields."

On page 7 of my Circular No. I50 you find explained why I had previously claimed that, by giving poultry, raised in sufficient quantities to do the work, the run about the fields during the period of emergence this "would certainly result in material reduction at small cost." Ask the Department what they have to attack the weevil with at this period. They have nothing. They deliberately want to convey the inference that it would be quite impracticable to have poultry in sufficient quantity handy, be- 


\section{( I 7 )}

cause, there being no use for it at other times, it would be impossible to have them ready during the period of emergence. They deliberately keep silent on the evidence shown on pages 8 to ro of my Circular No. I 50 , which describes in detail the feasibility of the use of poultry practically the year around, not on$l_{y}$ for the control of the boll weevil, but also of the boll worm, the cotton catterpillar and several other important cotton insects. They also want to convey the inference that there would not also be plenty of work for poultry on other crops, thus making it possible to economically sustain large flocks the year around.

As explained on page 8 the Bureau's plan of plowing out the plants in the fall, impracticable as it is on the whole, or the cutting off of the plants, forces the weevil to hunt for food, and, finding none, causes it to adapt itself to feed and breed upon plants other than cotton. As shown there, it is manifest that if this habit is allowed to become fixed, control by the destruction of the cotton plants in the fall, what there is of it now, will lose its value, and control will be made indefinitel more difficult. To counteract this tendancy, I showed there, as also in this Circular that the best thing that can be done, is to provide trap patches of very late planted cotton. The Department wants to keep quiet on this point, also wants to keep silent on how these trap patches incidentally make possible the complete control of the boll worm. Nor do they want to admit that poultry would pick on the fallen infested squares and destroy the grubs within, keeping up this work through all of the fruit setting season.

This habit of poultry of picking on fallen infested fruit I had shown can be taken advantage of in many other cases. Since the Bureau wants to keep silent I wish to point out that this habit is of very great value in the control of fruitflies, such as the apple-maggot or the Mediterranean fruit-fly, (Ent. Cir. No. I6o) because, it will be shown, this course is the only really feasible means of control.

Admittedly, for this group of insects, "no very successful means of control have been found." The Mediterranean fruit-fly 


\section{(18)}

has not yet invaded this country, so far as known, but it is in Hawaii, found there in I9Iо; and in Bermuda, supposed to be there for about 50 years. Hence, since it infests practically every kind of fruit, including the tomato, egg-plant, string bean, prickly-pear and pumkin, may have been brought into this country years ago, but by having plenty of chance to diffuse and by being similar in its work to the apple-maggot, may not yet have been noticed.

Because of the great range of food plants, wild and cultivated, little good can be expected from the collection and destruction of fallen infested fruit. As a result "in regions where the pest is well established, as in Australia and South Africa, much attention has been given to devising effective remedies, other than the collection and destruction of fallen fruit. A plan ... was the covering of the trees with netting and ... was thought to be practical. ... This plan apparently has not been followed to any great extent."

The only other known means that has any chance of success is the more recent use in South Africa of a poisoned bait sprayed over the trees for the destruction of the adult flies, evolved by Mr. C. W. Mally (Ent. Cir. No. I6o, page I 8 ). The results were surprisingly good. To get these results, however, it was necessary that the bait was evenly distributed over the trees, prickly pears, bush, etc., around the orchard.... Practically all the flies present during any one day found it very quickly and fed on it to their destruction..." (p. I9) I4 applications were thus made and the cost for material was about $8 \mathrm{c}$ per tree. What it cost with the labor added is wisely left out. Again, rains might interfere, and the application of the spray to fruit as it is approaching maturity might prove objectionable." Nothing is said as to what effect such continued poisoning would have on other insects, beneficial or neutral.

" "...When (the larva are) fully developed. which usually requires a fortnight or three weeks, they leave the fruit, which has as a rule fallen several days previously, and enter the ground, seldom going deeper than one inch, depending on the nature of the soil. There they soon change to pupæia and remain for $\mathrm{I} 2$ 
day's to three weeks, depending on the season....(p. I3).. Pupæ were present under some of the decaying peaches.,.. (p. I 8 ).

Thus poultry going about cultivated or wild vegetation ininfested, would simply have to pick on fallen fruit and thus either find larva within, or would, upon turning the fruit, often find pupæ in full view, while those not feasible will be found by scratching, usually within an inch of that very point, Hence, economical control of this insect, or of the apple maggot, clearly calls for the widest possible use of poultry; this is simply making a systematic use of a domesticated kind of natural enemy. "It (the Mediterranean fruit $\mathrm{fly}$ ) is without question the most destructive fruit pest on record in the world today." [p. ro]

"The Argentine Ant," the Department tells Mr. Raker, "is and insect which makes its nest in buildings.... Mr. Reinlein's plan is to use a plumber's torch to drive the ants, which he believes will carry their eggs and larva with them, into the open where it will be devoured by poultry."

Every word is a lie.

In Entomology Bulletin No. I22 you read: "At all the infested points the levee is found to be teeming with the ants and the batture itself is a constant breeding place... Here the ant colonies are found under every particle of drittwood and trash and during almost the entire year they are in attendance upon Coccidæ and Aphididæ upon the willows." Ask the Departmeni what means they have to control the pest there or on crops. whereby attending lice and scale insects they make, it is estimated by the Department, on the average 5 specimens grow where, in their absence, one formerly was found before.

The Department has nothing, absolutely nothing that is at all feasible. Just the same they want to deliberately fool the public by refusing to even admit that poultry raised in a systematic way to cope with such an enormous proposition has a chance to be of any value. This when they, in Bulletin No. I22 state that the ants, when unmolested, very greatly interfere in the raising of chicks, from which it follows that poultry is by nature an enemy of this pest. 
In summer time the ants appear to do as little excavating as possible and seem to limit their efforts to excluding light and water, etc. [E. B. No. I22, p. 56.] In case of danger the workers' first instinct appears to be to remove the young [egg, larva, pupæ] to a place of safety, and they readily sacrifice their own lives in order to accomplish this. [p, 4o] Thus poultry, given a chance, will simply scratch the whole combination up and eat them up. For a beginning, however, to get a flock established at this work in a badly infested locality, I had pointed out that it might be of benefit to assist them some. One way would consist in accelerating their destruction by the use of a blast torch, the kind shown on last page being a good type, and another way would consist in exposing quick acting poisoned sweets to the ants, which latter kills a limited number and drives the rest away from that particular place, giving poultry an undisturbed roosting place at night.

It is manifest that there is much wild land that needs clearing, and a man wishing to rear poultry there should be welcomed by any owner to do so, and this would result in a self-sustaining well paying business, but if this work could not be made to pay for itself, it would have to be done just the same, since there is no more feasible way known, and since without it the ants would be masters of the land, and stay masters.

On page I I of my Circular No. I 50 I made reference to A:sriculture Bulletin No. $37 \%$, giving the results of poison experiments to control the ants in houses. I showed on pages i I to I4 that the most feasible means to obtain this consists in first of all giving the widest possible use to poultry outside, and then control the ants that have gone to nest in the houses by exposing quick acting poisons, which kills a few and drives the rest away quickly, stating expressly on page 13 that, "the use of poisoned sweets for control in houses is a necessity." No talk about any torch at all. You probably did not look for any such skillful lying on the part of any Executive Department.

"The experts of the Department are of the opinion that Mr. Reinlein's plans are entirely impracticable....", the Department 
winds up its yarn. Then just let them point out what plans described in this circular are impracticable.

The Bureau makes no attempt to point out any means ot controlling any invasion of cultivated crops by the range caterpillar. There are no means that can be pointed out. Neither they nor anyone else has any, except it be continued hand picking. How entirely futile the use of arsenicals would be can be sathered trom a record of an outbreak of the yellow-bear caterpillar given in Entomology Bulletin No. 82, part V. "Judging from the results of these experiments, the arsenicals [applied to larva one-fourth to three-fourths grown, whereas the rang caterpillar invades the crop when nearly full grown, and is much larger] cannot be depended on to control." [p. 66] "On reaching maturity the larva crawl under heaps of dead weeds, tufts of grass.... In such quarters, which offer but slight protection they construct frail cocoons... There is no better method of fighting this species than to burn the weeds, grass etc., under which the pupæ, [of the hibarnating brood,] find protection...."

But there is a better way: Poultry given the run through such weeds, grass etc., will be able to get many of these pupæ. Besides there is also a Spring brood with insects in the pupael stage during summer even still lighter protected. This course of control I had shown in previous circulars to be applicable in many other cases; especially in the control of certain timber insects.

Whatever would burn is intended by nature to serve as protection for the plants and tor the animal life subsisting under their protection, for providing breeding ground for ground dwelling birds, for increasing humus, retaining moisture, preventing erosion. Hence, such burning, often recommended by the Bureau in similar cases, cannot be too strongly condemned.

Details for meeting the conditions that will be encountered in carrying on pultry raising on a large scale in the range caterpillar territory are given in my Circular No. I46, pp. 9 to I4. I may add that, since the succulent plants in that area are usually protected by strong spines, hence are not available for food, it is feasible, where they are available, to render daily a small 
patch of them fit for nourishment, since they then provide both food and drink. This can be done through the use of a cactus burner or a hot air blast torch. A suitable type is shown on the last page of this Circular. A little grain scattered through that patch will attract all of the poultry to that spot. A supply of feed can as readily be provided on the range as anywhere, through the raising, in suitable valleys, of grains adapted to semi-arid areas. It is also practical to raise green feed for winter feeding, since at least the necessary breeding stock has to be carried over, by the raising of root crops, hardy and not hardy, and of vegetable plants, hardy in that territory, such as kale and Brussel sprouts.

It is true that on page 12 of Bulletin No. 443 the Bureau claims cultivated cereal crops can be protected against the range caterpillar by spraying with a solution of one pound of powdered arsenate of lead to 50 gallons of water. But where are the tests to prove such an idiotic claim? The Bureau has found it necessary to recommend the use of 3 to 5 pounds of arsenate of lead to 50 gallons of water for the destruction of newly hatched larva of the browntail moth, then what can you expect from a third and fifth strength solution of this where "the full grown larva frequently measures $2 \frac{1}{2}$ inches in length, with the diameter of a man's index finger," (Bull. No. 85, p. 78 ) and where there is a continual stream coming in from the surrounding range?

All the essential features of this, and much other matter besides, was explained to Mr. Raker by the use of marlied and annotated copies of my Circulars No. I46 to I5o, and Mr. Raker was asked to hand this up to the iepartment for action, after having examined same. This he did, and he got the following reply: "The experts of this Department are of the opinion that Mr. Reinlein's plans are impractical. Apparently he is writing theoretically and without any first-hand knowledge of the insect concerned."

Thus seeing that Mr. Raker was giving me a chance at making a defense, they did not want to make any specific statement this time, and did expect Mr. Raker to let the matter rest upon their word that I am wrong, this when they had been asked 
to show why their previous letter had not been a bundle of lies. Naturally Mr. Raker was asked, under date of April i3th, to prosecute the matter further.

The far-reaching evils of erosion, their cause, their effect and tieir prevention, are described in Yearbood Separate No. 688, Farms, Forests, and Erosion. "In general anything that increases surface run-off, increases erosion... As a rule it is only when the natural protective cover of forests, brush, grass and other plants is disturbed that serious and long continued erosion results" (page 8 )

This is all new to the U. S. Entomolorist and his experts, judging by what they write. A good sample of what they write appeared recently in $\Lambda$ gricultural Bulletin No. 4r6; The Red Spider on Cotton. Under heading of Remedial Measures, you read on page 6o: "Too much emphasis cannot be placed on the importance of ridding all field borders, ditch banks, terraces, etc. of all vegetation as far as possible...."

Since cotton is only one of the $\mathrm{r}_{3}$ kinds of plants the red spider is known to feed on, emploring this means in this and in other cases as advocated by the Bureau, for instance in the destruction of hibernating quarters for the chinch bug and the boll weevil, would, a perusal of Separate No. 688 will convince you, in the course of a comparative short time, turn the country into a desert.

But aside from this I had shown throughout my Circulars No. I 39 to 150 that such destruction of host plants is all wrong, and that the correct way of control consists in using the preferred host-pants for traps if they are to be used at all as a means of control. Since the Entomologist has been talking for about a year to the effect that I am wrong all around, without offering a particle of proof, I now prove them to be wrong once more, from the latest available evidence.

On page 59 the authors state that the red spiders hibernate on several of the native and door-yard plants. "These hosts serve as sources of dispersion." Of course, what else could they do if not treated. "By destroying during winter and early spring 
polkweed, Jerusalem oak, Jamestown weed, wild blackberry, wild geranium and other plants which breed the pest, much good will be done. This plan has been tested by the writer in several instances and has given complete immunity the following season..." How these plants were destroyed is not stated, probably by burning and grubbing out. How about the next season? Has that work to be done over again every season? Of course with first choice food plants removed, the spiders will subsist on second, third and last choice plants. True, there is no practical way to treat the plants, especially in out of the way places, except by the way shown by me as far back as 1898 , by using the hot air blast, for which work the type of torch shown on last page is very suitable, 'These weeds are very often not on the owners land and, anyway, if on waste places; should be left there except to give something better a chance, which in turn, will also harbor spiders,

" ....In several instances of pasi severe annual infestation, violets" (probably the most favored winter food plant) "adjoining fields have been thoroughly sprayed, with the result that no red spider appeared in these fields..." 'Therefore you see if you only did treat these plants, they would act as traps instead of sources of aispersion. And hot air furnished by a torch is extremely cheap. Then again, since these plants may not be on the owners land, he can keep his crop clean by giving the plants near the source of infectation an occasional slight licking with a torch.

With a practical means of controlling them on the crop at hand, there is some very good reason why the winter host plants should be left to themselves. Anything that kills the spiders kills also, as a rule, the natural enemies that are present. If the host plants are not treated, they usually become heavily infested and in turn'much sought after by natural enemies of the spider, causing the latter to increase in number. As the spider does not spread fast the use of a torch near the edge of the field makes it possible to absolutely control invasion.

Again, taking cotton for a sample, this crop is attacked by many other enemies. Suppose infestation by red spider had 
been prevented through descruction of host plants, but the cotton aphis were taking a hold. Repeated slight swift lickings with a torch are far the best and cheapest means of control for this insect, and for aphis in general. On the other hand if nothing was done and red spider is invading the crop, the spider is thus being taken care of without extra work.

In thus using a torch other larger insects present will be noticed, because they start to run when they feel the heat from the torch, when they can be killed. A large part of these would require hand picking or expensive contact insecticides. However, as will be shown later in discussing boll weevil control, poultry can be made to take care of these.

It has been suggested to $\mathrm{Mr} \cdot$. Raker that the matter had reached a stage when it would be specially opportune to have him call the attention of Mr. Lever, Chairman of the House Co:n nittee on Agriculture, to it. As a result a letter was received from him May 8, containing the following: ... "It is my purpose to work with Mr. Raker or any other member of Congress that can and will give their assistance to this matter. The Department claims there is nothing in your idea, that you are wrong on all points."

Thus Mr. Raker himself has found no evidence that I am wrong. On the contrary wants to be shown if there is anything wrong about it. As for assistance, Mr. Lever is bound under the law to make the Department meet the issues. admit that I am right or else show what is wrong.

That poultry raising as a means of controlling certain insects can be made to pay, and pay big, is pretty conclusively proven by evidence presented in Year-book Separate No. 700: The Thanksgiving Turkey. There on page 4 you find an account of successtul turkey-ranching carried on "in the unsettled foot-hill region of California, and in certain sections of Arizona and other western states." If turkey can thus be profitably raised on a large scale in semi-arid, mountainous and very thinly settled sections, it is not clear why there should be any barrier to the systematic raising of chickens for both meat and eggs in the region infested by the range caterpillar, or elsewhere over low- 
priced land, for that matter.

Beginning with the melting of the snow after mid-winter, with insects then as yet completely inactive, and wild seeds scarce or absent, stems of grasses or weeds carrying the prominent egg-clusters of the hemilenca become the object of favorite attack by poultry. The insect is exposed to attack in this form as a rule, till June ist.

The larval period in the largest number of cases extends from June ist to September ist - three months. That the poultry would effectively attack the insect in the larval form is proven in Ent. Bull. No. 85, p. 93: "On July 27, 1909 two robbins were seen, each with a hemilenca larva in its bill.... By this date the majority of the larva are half grown. "The birds flew away with these..-apparently only of the smaller ones-as if intending to feed the caterpillars to their young." Thus if young birds can stand such young larva, it is safe to say that poultry can eat great numbers of the newly hatched and partly grown ones. And of course it is all a matter of the number of poultry on the job, whether any young larva would be left to grow hig. There is nothing objectionable about the pupæ. Skunks eat them greeily, although according to Chief Nelson of the Bureau of Biological Survey there is at present no evidence to show that they eat of the larva, big or small. The adults are in plain uiew, resting on stems of grasses during the day, hence subject to attack. Egglaying begins early in September, the species in this stage thus being subject to attack from then on till covered by snow.

All this, with much other matter, was in essence pointed out in my Circular No. I46, August 10, I91 5 . As the Entomologist has done nothing to satisfy himself as to the value of the evidence submitted, it will be well to see what he says about birds, as enemies of the gipsy- and brown-tail moth. The latter of the two seems to be the worst of all important hairy caterpillars as regards the nature of the hairs.... The presence of caterpillars of the brown-tail moth in large numbers was actually unbearable on account of the poisoning... (Yearbook Separate No. 706. p, 2) Birds have some importance as enemies. of the gipsy-moth..., 
pothunters..., have destroyed great numbers of insectivorous birds. "Much of the increase in the number of the pest is attributed to this." The caterpillars are preyed upon by the cuckoos, the Baltimore oriole, the yellow-throated vires and the blue jay." No destinction is here made between big and small caterpillars. "The moths are eaten by many birds, "which is pretty good evidence that poultry would eat the moths of the range caterpillar, "and the eggs are eaten by several species." (Farm Bull. No.

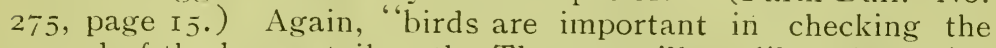
spread of the brown-tail moth. The caterpillar, like other hairy species, are not so much eaten by birds, except certain ones..... The moths... are preyed upon to a great extent by birds....", (Farm. Bull. No. 264, p. I8.)

In regard to controlling such insects by means of natural enemies, the Entomologist says in Year-book Separate No. 704, page 9: ".., with other kinds, ., which may exist in the egg stage, in a crawling larval stage, in a quiesent pupæl stage, and as a flying adult, and which in their native homes are parasitized by whole series of species of parasites, some attacking them in one stage and some in another, and still.others in a third, it is not such a simple thing to introduce and acclimatize the parasites necessary to reconstitute the normal environment." And admittedly these parasites are subject at any time to decimation by hyper-parasites.

Since the gipsy- and brown-tail moth are principally treefeeding insects, they are usually out of reach of poultry. But they are also often within reach. ..."It is a common habit with the larva (of the gipsy-moth) if they are disturbed, to spin silken threads which are attached to the trees, and in this way lower themselves to the ground." (Yearbook Separate 706, page 5) Thus if a larva lowers itself a few times with poultry on the ground, the lowering is apt to be stopped for good. "..., Of course the brown-tail moth is carried in the caterpillar stage just as is the gipsy moth" (through their lowering on silken threads) "upon vehicles of different kind passing through the infested region and upon the persons of pedestrians as well,... (Farm Bull. 264 , p. 13) "...small caterpillars [of the gipsy moth] immedi- 
ately after hatching may be blown long distances by the wind. It has been proved that spread oftell occurs from a distance of from I 2 to 20 miles in this way. [Y-Sepr. 706, page 5]. How to get rid of such scattered caterpillars the Bureau has not the slightest suggestion to offer. With the woods patrolled by poultry for this and other pests, such as the brown-tail moth and the tussock-moth, this would keep the incipient pest in check. There is no means of extermination. The gipsy moth has been discovered as far west as Cleveland, O. Being an isolated case, everything humanely possible has been and is being done to stamp out the pest. But with young caterpillars having been blown 12 to 20 miles it cannot be told for years with any degree of certainty whether the attempts at extermination have been successful.

"Over half a million dollars is the yearly expenditure [for the control of the gipsy moth] in Massachusetts at the present time." [Y. S. No. 706, p 8,] This is for work by towns and cities. In the woodlands the gipsy moth multiplies unhindered. It will be seen then, that unless the moth there is kept in check - and poultry is the only means in sight, the Bureau having nothing to offer but parasites and elimination of favorable food plants, such as oak--with the young capable of being blown for miles, there will be a constant reinfestation of cleared areas from this cause alone. This alone explains why "it is inevitable that new colonies will be found from time to time outside the region now known to be invested,.." Thus in Dep. Agr. Bulletin No. 273 , p. I 8 it is estimated that the wind blows 2 Io million small larva annually into the ocean, and the number is probably much greater. It also emphasizes the necessity of keeping this moth confined to New England territory if rapid and general spread over the United States is to be prevented."

In Year-book Separate No. 704, p. I4, the U. S. Entomolgist says: "On the whole, the work [of importing parasites of the gipsy - and brown-tail moth] has been very successful, and has helped in bringing about infinitely better conditions in New England so far as these pests are concerned, and while it is practically certain that both the gipsy moth and brown-tail moth will 
gradually spread westward, it is equally sure that the imported natural enemies will go with them, and that none of the long continued disastrous outbreaks which we saw in Massachusetts in the years prior to 1905 will occur further west."

Let us see: "...A large part of the funds expended by towns and cities (in Massachusetts over half a million dollars a year) has been used for the protection of shade and ornamental trees, it having been found impossible to carry on extensive work in woodlands, owing to the extreme cost of these operations. The beauty and attractiveness of most cities and residential sections depend on the trees...." (Y. S. No. 706 p. ro) That means that no funds were spent in woodlands except a little for experimental work to find out that such work as is done in cities and residential sections involves their "extreme cost." The fact is the woodlands are not accessible to spraying machinery, and moreover represent far too low a valuation for this and all of her artificial means of control, hence the insect there is left to breed unchecked. The "long continued disastrous outbreaks" have been and are existing there right along. "Enough pressure was brought to bear, however, in the fall of r $89 y$, to cause the discontinuance of State appropriations for the control of these insects... Matters became so serious in 1905 that work was resumed by the Commonwealth of Massachusetts..." Thus you see the "disastrous outbreaks" this humbugologist speaks about referred to conditions in towns and cities during a period when the state spent no money for 5 years.

The "infinitely better conditions" thus leaves the country at large without control, and as for work of the parasites, the insect does sufficiently well in spite of those to require the use of half a million dollars in towns and cities in Massachusetts alone. Poultry is a natural enemy of these and other insects, the only natural enemy that can be definitely controlled by man in its work, hence should for control in woodlands and farms, form the chief reliance in control.

As for control in cities and residential sections this could be simplest secured through trapping the adults, in the case of the 
gipsy moth of the male only. If woodlands and farms are controlled by poultry the number of brown-tail moths congregating in cities will correspondingly decrease, and thus greatly reduce the necessity for control there. If you will see to it that your Congressman uses hls influence to see to it that action is taken on the matter in hand, I propose to show you how these moths can be trapped in vast numbers at surprisingly low cost. Until this is done you will have to look to the Secretary of Agriculture and his experts to show you how this trapping is done.

Mr. A. S. Weiant, the author of Year-book Separate No. joo was asked to tell what he knows about poultry as a means of controlling insect pests. He said to do this one should be an entomologist. Speaking of turkeys as largely occupying his attention, Mr. Weiant says: "As a means of lieeping down grasshoppers I can vouch for them." There is no good reason why chickens should not answer as well. If so, this then simply proves that I was right when I said as far back as in my Circular No. 147, p. I5, that the correct means to control grass-hopper outbreaks consists in judiciously using poultry: that since their stronghold is in the high, dry, rocky lands, dangerous invasions from that source can be prevented by having large flocks of poultry roam over these otherwise nearly idle lands. Over further on Mr. Weiant says: "Turkeys are naturally great rangers and when given the opportunity can pick up the most of their food in meadows, grain fields, pastures, alfalfa fields, etc.'

Then why not raise enough of them to utilize all of the existing opportunity? And why should chickens not do as well? I have noticed in the South that turkeys spend very little time in the cotton fields provided there are any pastures or grain fields to roam in. This is just what one would expect. Meadows, grainfields and woodlands offer far better feeding than cotton fields early in the season when poultry will be wanted to be kept in cotton fields on purpose as needed, the shortness of food supply forcing them to hunt for weevils and attack fallen infested squares, pick up Argentine ant workers to keep them from fostering aphis infestation, during which they render far more value in spite of requiring more grain and more attention, than they would by consuming food where it is more plentiful. 
"An insect must become quite common before it can form an appreciable portion of the food of (wild) birds..." Bul. Io7, page 2. If so, you cannot expect wild birds much to reduce the boll weevil, since being multi-brooded, reduction in number of hibernated adults is what is most needed, and a small number is admitedly easily able to produce an off-spring large enough to destroy the crop.

"The natural food of the turkey consists of insects, green vegratation, seeds and nuts of various kinds." On page 4 of Year-book Separate No. Too Mr. Weiant points out that turkeys greatly relish acorns and that where these are plentiful but little grain need be used for fattening them in the fall, which fits in nicely with turkey raising in the woodlands of New England, consisting as they do largely of oak, as a means of keeping down gipsy- and brown-tail moth infestation. "Of the insects turkeys seem to prefer grass-hoppers to all others, hut they will also eat circkets, grubs and worms of various kinds, flies, butter-flies, moth, etc." There is no reason why they should not eat of the hemilenca moth (range caterpillar). These being on the urass-stems in plain view, simply waiting to be picked. As at that time, late fall, there are hardly any grass-hoppers, they represent the food most easily available.

"Some insects they appear to let strictly alone. For example I have never seen a turkey eat an ant. a caterpillar, or a potato bug." Now ants may be too small, besides they might eat them in the form of larva and pupa, if not as adults. As to caterpillars, if fully grown hairy ones are meant by this, it is correct enough. How about the small and spineless ones? Only careful tests can tell.

As to what birds do in the way of destroying the Argentine ant you read on page 73 , Ent. Bull. No. I 22: "On one occasion Mr. G. A. Runner observed an English sparrow industriously picking up the Argentune workers from a trail which crossed a wide roadway at Baton Rouge. This habit is not, however, a common one with this bird." If this sparrow could get at nothing else, a condition that can be imposed on poultry, the habit would become common at once.

"The flicker, or yellowhammer, Calaptes auratus, has of- 
ten been seen industriously digging up shallow ant nests in lawns and grass plots, evidently for the purpose of obtaining the pupa and larva, and should doubtless be credited with being the most important natural enemy which this ant has in the South.,." What the Entomologist was wanted to show all along was why poultry would not also dig up these nests.

Speaking of poultry catching moths, it should be borne in mind that the adults of some borers most difficult to control are moths.

Take the sugar cane moth borer. This insect is, in Entomology Circular No. I39, p. 2, conceded to do enormous damage. Figures there given place the loss on plant cane alone used in one factory in three years previous to 1912 at $\$ 145,445$.

Since the U. S. Bureau of Entomology has published very little in regard to the life history of this insect, I asked Governor Pleasant of Louisana for the favor to request his State Experiment Station to send me a copy of their Bulletin No. 7o, second series: The Cain Borer. This was done. The remedies there given consist in substance in planting the cane as near as possible in the fall, burning all trash, and of culling cane and corn in the spring. The borers in the buried fall-planted cane are not able to emerge as adults through anything as thick as one-half inch of loose soil. "The windrowed areas should be systematically gleaned after removal of cane for spring planting and all pieces of cane destroyed by fire or carefully buried..." [p. 923] "all trash [cane tops] should when cut be so arranged upon the cane rows as to hasten drying and whenever dry should be fired...." (p. 924) The borer's "only tood in Louisana has been found to be sugar cane, corn, Johnson grass, Guinea corn, sorghum, (sweet and sour-sweet) and possibly two other large grasses." (pałse 927.)

But to burn or bury all waste is a pretty big job, besides burning any kind of vegetation means a loss. The Department of Ayriculture fathers the statement that "the burning of a wheat stubble deprives the land of as much fertility as the producing of five crops of wheat." If so the main loss is sustained through the action of the fire upon the soil. 
. Everybody [with but few exceptions] burns the trash... ret with this only known effort practiced alike in every community, the borer multiplies to a destructive extent in one section and is practically subdued in another." (p. 902)

Thus you see the need for something better, or at least for some effective additional means of control. "If fall planting on$1 y$ be made... the enclosed borers must remain until the cane is scraped in the spring and the few which will then escape would be hardly enough to produce much harm durings the summer..." (page yo4).

Let us see: On page 925 is given the record of a cane culling bee. 420 acres were culled in the early spring, filling 120 sacks, each having 333 borers, or a total of 39960 , this makes a catch of 95 , say roo borers to the acre. A female lays on the average 300 eggs. Thus one female emerging from every 3 acres of scraped cane might do all this damage. Suppose ro infested stalks per acre of first brood were missed. This gives us five resulting females, at 300 eggs each, or 1500 borer of second brood during say, June-July. 750 females will result, at 300 eggs each you have 225 , ooo borers of the third brood during August-September: and 3,375 , ooo par acre for the $4^{\text {th }}$ brood during OctoberNove nber. While such numbers do not occur, more likely because of cannibalism than of all other causes combined, it shows that the insect has the faculty to increase to such numbers as can subsist under such competition.

"Corn is more succulent, more rapid in development and thus in the economy of the borer assures the development of many more specimens than if cane were the only food plant of the first two broods..." (page 912). Infestation of young corn is shown to be about ten times heavier than cane. (p. 912)

Investigations have shown that 87 per cent of the moths $e$ merge prior to April I 5 th. Moths come from the pupa cases at night and after expanding their wings remain hanging to some plant or other object during the entire following day. The second night mating takes place and a few eggs may be deposited.. The moths are not shy and unless vigorously disturbed will not take flight during the day..., (p. 9io). 
Since windrowed areas produce the largest number of moths, a stand of young corn there, with the moths hanging on the plants can be made to serve as a trap, since, the poultry given access: the moths can be largely secured. In the past the advice given was that "...limited tracts of corn badly infested with the borer in close proximity to cane should be completely destroyed to protect the cane crop from succeeding broods..." (p. 925.); now with poultry at work there is no need of reducing the acreage of corn, or abandoning corn for a year or more, as recorded on page 9r4 to have been found beneficial in preventing heavy infestation of cane.

"...few if any moths emerge during the colder months of winter...(p, gro) ...the moths while existing in small numbers confine their attacks to the ends of the rows and to the ditch bank rows..." [p. 903]. This either means that the earliest emerging adults have wintered outside of the fields hidden. away under some heavy vegetation, or else it means that the insect has hibernated as larva on plants on the ditch bank and more adults have developed there early than did in the fields; or it means both. At any rate the thing to do is, instead of planting no corn, to plant corn by preference in the ditch bank rows and as near as possible at the ends of the rows, and to protect also the interior of the field by strips of corn, kept patrolled all through the season by poultry. It is obvious that there must be always corn on hand that is young. To this end two crops of corn are grown on these strips, some corn, beginning on March Ist. being planted at intervals of one month up to September ist. While harvesting of cane is going on and before there is frost, the borer, with corn present, planted August ist and September Ist, will virtually confine oviposition to these savings. These should be left standing. A legume can and should be sown between at the last cultivation. Stock may be admitted after frost and the whole thing must be plowed down nicely before the beginning of emergence, say before Match roth.

If poultry be not used, it will be readily seen that the normal requirement of corn could not be produced without endangering the cane crop unless a great deal of care is used culling 
the corn. It would not seem feasible to cull millet by hand, hence under the old system millet inust be left out of the crop rotatian.

As practically all of the cane growing area is overrun by the Argentine ant, poultry is needed all through the summer to pick up the workers to prevent undue multiplication of the measly bug and of aphids. Besides there are numerous other insects affecting corn and cane, and other crops necessary-to allow at least of some diversification, which poultry can be more or less successfully used to control.

Another highly injurious day-flying moth is the adult of the peach-tree borer, which deposits her eggs at the base of the trees. Poultry allowed to roam through the orchard with a view of keeping down insects in general, would secure a certain number of these, reducing the need for other means of control.

A day-flying moth that does very similar work, ovipositing at the base of the trees, is the sequoia pitch moth. It is at pres. ent the most destructive insect to the large pole pines in certain parts of Moniana. Poultry made to roam the woods in sufficient quantity for controling insects in general would increase the use of the land and to a certain extent keep this pest in check.

In his report for I9I6 the Entomologist makes the claim that tests are boing carried on by the Bureau of Entomology that hold out the possibility of a chance of discovering successful mathods of preventing the establishnent and spread of the pineshoot moth, and of the European pine-saw $\mathrm{Hy}$, both "introduced shortly before the plant quarantine act became operative." [p. I6]. The first named insect has been introduced, as stated in Agr. Bull. No. I 70 , as far back as IgIr, was found in rgit in 20 localities in nine states, in one case, the work then being 3 vears old. Both sexes are strong fliers, laying their eggs in the apical and other terminal buds of pine trees, thus offering not the slightest chance of extermination as explained in detail in my Circular No. I 45 and $\mathrm{I}_{4} 6$. Yet even as late as this the Entomologist wants to humbug the people into believing that its establishment can ret be prevented, when for means of control it has nothing but the remoral and burning of the infestedshoots. 
In the case of the European pine-saw fly, extermination is, if possible, even more broadly impossible. The adult is a fly. The eggs are laid in the needles on the tips of the trees. The insect was discovered in August rgit in Connecticut. It has two broods, which means rapıd dissemination. This insect, together with the larchworm, it was shown on pages 16 and $\mathrm{I}_{7}$ of $m y$ Circular No. I49, has been decribed rather minutely in the report of the Connecticut State Entomologist for 19I5. Mr. S. A. Robicer of the Bureaa of Entomology at Washington, is there quoted as saying that ".... it has a large number of host trees" [in Europe] "and would no doubt adapt itself readily to the conditions in America....." [Rep. Conn. Ent. I915, p. II9]. Thus extermination if attempted, would involve examination of pines and other conifers for many miles around the original infestation means of extermination there are none. As to means of control. "It is eivdent that Diprion simile is freely attacked here by American species of parasitic Hymenoptera and Diptera, but it is not known as yet whether any Europeean species were brought into this country in the cocoons of the sawfly". Other practical means, necessary when the parasites fail, the Entomologist has none. The use of poultry makes it possible to secure the larva as they spin down or fall down occassionally, or when they migrate over the ground to other trees. The larva being hairless should make choice eating for poultry. "In Europe raking up and destroying the leaves and other rubbish under the trees in the fall is recommeded to distroy the cocoon." [p. I23]. A far better way would be to have the cocoons scratched up and eaten by poulury.

The larchsaw fly is single brooded, spends the winter in a cocoon beneath rubbish on the ground and thus can easily be controlled by poultry, besides the caterpillars are subject to attack when on the ground.

This insect "invariably chooses the young, green, terminal twig in which to insert the eggs.., When the apical terminal shoot is affected... a permanent kink may be caused... It is an injury which cannot be prevented..." page 127. Poultry, by keeping the insect down to limited numbers will prevent the in- 
sect from laying any great number of eggs into any one shoot, and thus prevent any great injury to apical shoots.

This saw-fly "during several extensive outbreaks since I 880 has killed from 50 to ioo per cent of the mature larch over vast areas in the north-eastern United States and south-eastern Canda.,.aggregating many millions of feet." (Rep. Conn. p. 6o) The chief factors in the control of the larch saw-fly are its natural enemies, which consist of birds, mammals, a large number of parasitic and predaceous insects, and a fungus disease." (Rep. Conn, Ent. p, I30). But since outbreaks do occur with this and many other insects of similar habits, why not use poultry when and where it is needed?

Since the Entomologist talks about half of his time about what great good parasites, native and imported, are doing as the result of the work of his Bureau, it is well to see what the pine shoot moth has done in Europe in spite of its parasites, and "in spite of continued preventative war against it.., If the attack is slight, it results in the branching of the tree," (since, if uninfected, the moth selects the apical bud for oviposition) "but if the attack is severe and continued for several years, as we have seen it, then hardly any bud is spared and the pines become stunted into miserable small bushes..." (Dept, of Agr, Bul. No. Iтo, p. 2.)

"It is reasonable to suppose that some of the native parasites on some of the native species of Evetria will in time also attack Evetria buoliana (the imported pine shoot moth) in this country - in fact parasitized larva have already been observed but these native parasites cannot be relied upon to keep in check their natural hosts, the American pine shoot moths, which sporadically become very abundant and very injurious, in spite of the parasites and presumably will be less effective in controlling the newly introduced host." (p. 9.) "None of these native species (of pine shoot moths) can, however, even with this advantage [of having two broods annually] be compared in destructiveness to the European species just introduced..."'[p. 8]

Since chiefly young trees are chosen for oviposition, I had shown in my Circular No, I45, page $\%$, that the sensible thing 


\section{$(38)$}

to do is to protect, if possible, the apical bud in some way when the adults are about laying their eggs, the most feasible way appearing to me to be the pouring of some semi-liquid clay over the apical bud, causing thus the moths to oviposit on a side shoot, which serves just as well. I also described in my Circulars No. I45. I47 and I49, pages I 3 to I5, how these moths and cther night flying insects might be trapped.

Virtually all this and more was shown in my Circular No. I45, June 7 , I9I5, The Chairman of the Congressional Committees on Agriculture, Senator Thomas P. Gore and Representative Asbury F. Lever were urged to have the U. S. Entomologist either admit this to be correct, or else show why it should not be correct. Pouring semi-liquid clay over the apical bud either protects it or it does not protect it. "Early in August [in Europe) the eggs are laid singly on the new buds of the next years growth..." page 5. The adult will not of course, oviposit on hardened clay, when she has plenty of side shoots" serving fully as well. The Chairmen mentioned therefore should have forced the Entomologist to define his position. And this applies to all issues involved.

Protecting the apical bud by an application of semi-liquid clay may be a simple enough idea. On the other hand this insect "has been the subject of much study and of an extensive literature from the time it was first described by Schiffermiller in I 76 to the present day." The U. S. Entomologist frankly says his Bureiu is the best thing of the kind on earth. The fact remains, no one has pointed out this simple idea before; and now the Entomologist wants to pretend to be unable to see any good in it. And Messrs. Gore and Lever thus far, have wanted me to be hanged on that pretense.

The apparatus shown on last page was designed with a view to meet the needs for an apparatus, that will enable the man having a limited amount of vegetation, ranging in size from big trees down to grasses, to keep same free of insects and fungi. In a ferw cases, with the codling moth for instance, the proper use of arsnicals is the best thing at present known, but in the case of all sucking insects, and in any case where poison is 
for one reason or another not satistactory against biting insects, with the exception of where they can be controlled by poultry, or by trap crops, or by the torch used as a trap at night, the use of heat is far preferable to employing the contact insecticides now officially recommended.

It may be well to mention here that now flour mills and other buildings infested by insects are being fitted. as the best means known for control, with heating apparatus of such capacity that insects may be killed simply by giving so much heat that they will die purely because of high temperature, doing away with the many objections incident to using poisonous gases.

The use of heat from a torch, was first described by me in in I 808 and was first used by me in 1896 as a means of controlling the harlequin cabbage bug. In his report for IgÍ the Entomologist on page i 8 says: "... Such remedies as trap-crop planting and the destruction of the bugs with special burners are among the most successful," in combating the harlequin bug. As for the trap crops, I had shown as far back as 1898 the adult bugs congregate on the tassels of sweet corn. More recently I have shown that by seeng to it to have at all times some cruciferous plant going to seed, the bugs will congregate on the seedstalks and can be kept down by poultry, doing away with the use of heat, special or otherwise. But old or new, according to the Entomologist I am wrong either way.

The adult harlequin bug lays her eggs on the underside of the leaves of cruciferous plants, which leaves are mostly inverted spoonshaped; hence the young bugs usually cannot be seen without moving the leaf. Because of this the simplest means of control consists in concentrating the adults in plain view upon tassels of sweet corn or seedstalks of cruciferous plants. They then cain be picked off by hand or by the use of poultry.

On page Iy of his report the Entomologist speaks about the control of the spinach aphis by lady beetles in the truck district of tidewater Virginia. He says "the extensive cutting down of trees and removal of underbrush for planting of truck crops left us available places for the ladybirds to hibernate..." Then how 
does he expect these ladybirds to become and stay plentiful in the fields, since, moreover, they go to feed on lice on most of the crops and since all these crops need treatment as to insects and fungi, which treatment of necessity also kills the ladybugs. $\mathrm{He}$ says the plants cannot be reached, even with an underspray. I claim there is an "underspray" that reaches them, that is, reaches the lice hidden in the hollows of the inverted spoonshaped leaves, especially when the plant is growing nicely in the spring. And this spray consists in the use of heat as applied by a torch. Some kind of knapsacktype torch is the thing to use and the essential feature in its use is to use it early, often, and swiftly, letting the heat blow slantways upon the ground a few inches from the plants as they are approached. The heat waves will then roll in between the leaves.

Without thus controlling the aphids, on the spinach, this crop will act as a winter host on a large scale for this and various other kinds of aphids, resulting in abnormally heary infestation of succeeding crops.

The special features of the apparatus shown consists in that the handle of the pistonrod of the pump located in the center serves also as a hook, making it possible, after remoring the shoulderstrap, to hook the apparatus from branch to branch in a tree. This does very well with the man having but few trees, making him independent in his work, since the official recommendations call for something else in many difterent cases.

For big trees in large numbers. I have described on pages I I to 13 of my Circular No. I47 how suitable apparatus furnishing heat can be gotton up. Heat thus applied is far the best means to destroy the stem mothers of aphids and the adult pcarthrips as they congregate upon the bursting buds of fruit trees and fruit bushes.

I had also shown how apparatus applying heat to lowgrowing vegetation, such as oats infested with the spring grain aphis, can be constructed, using, if desired, as far as practicable fittings from the outfit used for orchard work. 
The spring grain aphis is usually held in check by natural enemies-for details see Ent. Circular No. 93, Revised. The natural enemies rather often fail. The latest occurrence was right in 1916 , as recorded on page 12 of the report. On pages I 2 and 13 of my circular No. I44 I had shown at some length that the Entomologist has no tangible means of control. The use of heat does destroy the pest and should come into effect as soon as the danger of an outbreak becomes apparent.

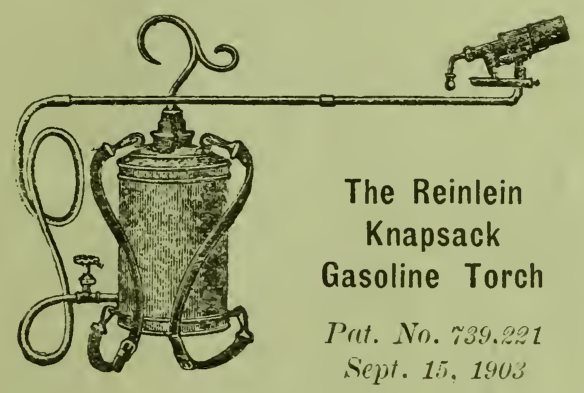


